\title{
INTENSIFICAÇÃO DO TRABALHO, ALIENAÇÃO E EMANCIPAÇÃO HUMANA
}

\author{
Eraldo Leme Batista ${ }^{\mathrm{i}}$ \\ Paulino José Orso ${ }^{\text {ii }}$
}

\section{RESUMO}

Neste artigo, nos propomos discutir sobre os processos de trabalho na atualidade. Partindo do pressuposto de que o trabalho se constitui na categoria fundante do homem e da sociedade, numa palavra, na razão de ser do homem, a partir da produção marxiana e marxista, analisamos como o trabalho produziu o estranhamento do homem, cavou a alienação. Assim, a produção se tornou fetichizada e passou a dominar o próprio produtor, que, quanto mais intensifica a produção, seja por meio da mais-valia relativa ou da absoluta, mais empobrece, emburrece, embrutece e pauperiza o próprio trabalhador, fazendo a alegria dos não produtores, os capitalistas. Depreende-se, portanto, que, de acordo com o que e como produz, o homem também é educado de determinada forma pelo trabalho. Diante disso, impõe-se o imperativo da desalienação do trabalho, de uma nova educação e da indispensável supressão da propriedade privada dos meios de produção e da emancipação humana.

Palavras-chave: Trabalho; alienação; emancipação humana.

\section{INTENSIFICATION OF WORK, ALIENATION AND HUMAN EMANCIPATION}

\section{ABSTRACT}

In this article, the result of joint research, we suggest discussing today's labor processes. Assuming that labor constitutes the foundational category of man and society, i.e., man's reason of being, we analyze, based on the Marxian and Marxist production, how labor produced the estrangement of man, how it resulted in his alienation. Production has become fetishized and has gradually dominated the producer himself, who, the more he intensifies production, either by means of relative or absolute surplus value, the more he impoverishes, addles, brutalizes, and impoverishes the worker, to the delight of the nonproducers, the capitalists. It appears, therefore, that, according to what and how to produce, man is also educated in a certain way at work. Thus, we need the imperative of alienation from work, a new education and essential suppression of private property ownership of the means of production, and of human emancipation.

Keywords: Labor, alienation, human emancipation.

Observamos cada vez mais que, com o emprego de tecnologias mais avançadas no processo de produção capitalista, tem contribuído para que a produção de mercadorias se dê de forma cada vez mais rápida em todos os setores, inclusive na educação, fazendo com que o trabalhador produza mais com menos tempo de trabalho. Assim, gera mais lucro para o capitalista em menos tempo e produz mais-valia em tempo menor. 
Ao descrever estas modificações no processo produtivo, Marx afirma que:

Para fazer, no mesmo tempo, dois pares de botas, tem de duplicar a força produtiva de seu trabalho, e ela não pode duplicar-se sem a alteração em seus meios de trabalho ou em seu método de trabalho, ou em ambos ao mesmo tempo. Por isso, tem de ocorrer uma revolução nas condições de produção de seu trabalho, isto é, em seu modo de produção, e, portanto, no próprio processo de trabalho (MARX, 1989, p. 238).

A reflexão feita por Marx, nos mostra que, muitas vezes, a completa transformação dos meios de produção, ou seja, a introdução dos avanços tecnológicos, máquinas computadores, entre outros, possibilita ao capitalista amplas possibilidades de agilização do processo produtivo e consequentemente de extração de mais-valia.

Apesar de Marx já ter verificado a aceleração do processo de produção e de ampliação da exploração no século XIX, suas reflexões, como se pode observar abaixo, parecem ser ainda mais válidas para os dias atuais.

Tem de revolucionar as condições técnicas e sociais do processo de trabalho, portanto, o próprio modo de produção, a fim de aumentar a força produtiva do trabalho, e mediante o aumento da força produtiva do trabalho reduzir o valor da força de trabalho, e assim encurtar parte da jornada de trabalho necessária para a reprodução deste valor (MARX, 1989, p. 239).

Marx, ao falar sobre a mais-valia demonstra que a mesma é o excedente produzido pelo operário, diferenciando a mesma em mais-valia relativa e mais-valia absoluta. Para o autor, a primeira ocorre, por exemplo, numa indústria altamente mecanizada em que, pelo aperfeiçoamento da tecnologia, aumenta a produtividade, ou seja, num mesmo número de horas trabalhadas se produz uma quantidade maior de mercadorias. A mecanização, além disso, faz com que a qualidade dos produtos dependa menos da habilidade e do conhecimento técnico do trabalhador individual. Numa situação dessas, portanto, quanto mais a força de trabalho produz, menos ela vale, ou então, ela empobrece tanto quanto mais ela produz.

Mesmo que o avanço da tecnologia era menor em sua época, Marx (1989) já analisava o aumento da extração de mais-valia relativa, através da qual os trabalhadores são obrigados a produzir mais em menos tempo. Para Marx:

Não há a menor dúvida de que a tendência do capital, uma vez que o prolongamento da jornada de trabalho lhe é definitivamente vedado por lei, é de ressarcir-se mediante sistemática elevação do grau de intensidade do trabalho e transformar todo aperfeiçoamento da maquinaria num meio de exaurir ainda mais a força de trabalho, o que logo deve levar a novo ponto de reversão, em que será inevitável outra redução das horas de trabalho (MARX, 1989, p. 37).

Para lidar com todo este processo, numa complicada teia de máquinas programadas por computador, o capitalista necessita de um novo trabalhador que saiba não só operar essas tecnologias, mas que também, contraditoriamente, conheça o próprio processo produtivo, que no passado não era possível aos trabalhadores. 
Em sua época, Marx talvez não pudesse imaginar o avanço tecnológico em que chegamos nos dias atuais. No entanto ele conseguiu prever o surgimento dessa mão-deobra qualificada para operar essas máquinas.

Surge um pessoal numericamente insignificante que se ocupa com o controle do conjunto da maquinaria e com sua constante reparação, como engenheiros, mecânicos, marceneiros etc. É uma classe de trabalhadores, em parte com formação científica, em parte artesanal, externa ao círculo de operários de fábrica e só agregada a eles. Essa divisão de trabalho é puramente técnica (MARX, 1989, p. 40).

Uma das alternativas que os capitalistas encontraram para acelerar o ritmo do processo produtivo e, com isso, fazer com que o trabalhador produzisse mais em menos tempo foi através da parcelarização da produção em tarefas delimitadas e restritas, nas quais cada trabalhador efetua a sua parte sem conhecer a totalidade do processo, como denuncia Braverman (1987):

O modo capitalista de produção destrói sistematicamente todas as perícias à sua volta, e dá nascimento e qualificações e ocupações que correspondem às suas necessidades. As capacidades técnicas são daí por diante distribuídas com base estritamente na 'qualificação'. A distribuição generalizada do conhecimento do processo produtivo entre todos os participantes torna-se, desse ponto em diante, não meramente 'desnecessária', mas uma barreira concreta ao funcionamento do modo capitalista de produção (BRAVERMAN, 1987, p. 79).

O esfacelamento do processo de produção em pequenas tarefas, além disso, permite extrair um rendimento muito maior dos trabalhadores, tanto em questão de tempo como de aumento de produção (mais-valia relativa).

[...] O modo capitalista de produção está continuamente se expandindo a novas áreas de trabalho, inclusive aquelas recentemente criadas pelo avanço tecnológico e o emprego do capital a novas indústrias. Está, ainda, sendo continuamente requintado e aperfeiçoado, de modo que sua pressão sobre os trabalhadores é incessante. [...] A necessidade de ajustar o trabalhador ao trabalho em sua forma capitalista, de superar a resistência natural intensificada pela tecnologia mutável e alternante, relações sociais antagônicas e a sucessão de gerações, não termina com a 'organização científica do trabalho', mas se torna um aspecto permanente da sociedade capitalista (BRAVERMAN, 1987, p. 124).

É imprescindível para o capital ter o controle sobre o processo produtivo, pois o trabalhador para que produza sempre mais e sendo ele o agente deste processo, pode procurar formas de amenizar a exploração e pressão exercidas pelo capital. E a tecnologia vai servir a este fim, pois, dada a sua complexidade de detalhes e constante evolução, o próprio trabalhador não consegue obter um conhecimento pleno, estando sempre à mercê do capitalista para sua atualização técnica, já que um profissional que não esteja correspondendo às expectativas da tecnologia poderá ter seu emprego ceifado.

Ao refletir sobre esta questão, Julio (2003), destaca que os novos processos de trabalho determinaram a penetração do trabalho na vida privada do trabalhador, para além da jornada de trabalho oficial. 
O potencial tecnológico, ao invés de criar o tempo livre, criou a necessidade do trabalhador despender o tempo de descanso dos períodos noturno e dos fins de semana com treinamento profissional contínuo a serviço das necessidades do capital. O tempo de lazer e do descanso foi invadido com o trabalho não remunerado de forma indireta sob a forma de qualificação profissional, além disso o treinamento profissional que os trabalhadores praticam não trazem benefícios para eles, são treinados para o capital e não para si mesmos na medida em que suas qualificações têm que acompanhar a deteriorização acelerada e crescente das forças produtivas. A necessidade de buscar a contínua qualificação transformouse em uma obrigação por meio da concorrência praticada entre os próprios trabalhadores como pressuposto de conservação no posto de trabalho (JULIO, 2003, p. 133).

Quando a produtividade foi ameaçada pela limitação da jornada de trabalho, o capital respondeu com a intensidade de trabalho, isto é, com a aplicação da ciência à produção e a subsunção real do trabalho ao capital. Outra autora que reflete sobre este processo é Tavares (2004) afirmando que:

O desenvolvimento das forças produtivas assegurou não só o aumento da produtividade, como rompeu com a necessária habilidade do trabalhador, para vir da máquina. A partir desse momento, o meio de trabalho tornouse um concorrente do trabalhador, pelo qual o capital não se sente responsável, pois sua meta é acumular e não criar empregos (TAVARES, 2004, p.92).

Cumpre destacar também que, com a fragmentação e "especialização" do trabalho, ao invés de ocorrer um aperfeiçoamento e um enriquecimento do trabalhador, inversamente a isso, ocorre um empobrecimento também do ponto de vista do conhecimento e da humanização, uma vez que seu escopo de racionalização do trabalho fica limitada apenas à parcela executada.

Com o fenômeno de reorganização global da força de trabalho, rearrumação, redivisão ou qualquer coisa similar, o que se tem é um articulação dos regimes de maisvalia relativa e mais-valia absoluta, mediante um conjunto de formas de produção de mercadorias modernas e arcaicas, cujo propósito é tão-somente uma adequação ao processo de valorização do valor, indicando que é possível esticar ainda mais o conceito dos níveis aceitáveis de desemprego. Observa-se que, enquanto a dinâmica capitalista está efetivamente desempregando no regime da mais-valia relativa, expandem-se as atividades informais em regime de mais-valia absoluta, o que mobiliza a esfera jurídica no sentido de criar mecanismos que garantam legalidade a velhas formas de extração de sobretrabalho, como as cooperativas, por exemplo, que o modelo de acumulação flexível ressuscitou. (TAVARES, 2004, p.70)

Ao invés de serem destruídas, as atividades extensivas em força de trabalho são incorporadas mediante articulação da mais-valia relativa à mais-valia absoluta, revelando, por um lado, a desigualdade espacial do uso e da remuneração da força de trabalho e, por outro, que ser dominante não quer dizer exclusiva: mais-valia absoluta e mais-valia relativa conformam uma unidade. No entanto seus efeitos atingem especialmente os países menos desenvolvidos, onde a escala de utilização do trabalho informal tende a ser maior. (TAVARES, 2004, p.103). 
No momento atual o capital combina tanto a mais-valia relativa quanto à mais-valia absoluta. Esta articulação é amplamente facilitada pelos processos de terceirização, responsáveis pelo aprofundamento da desigualdade entre os trabalhadores. As maiores empresas, dotadas de tecnologia mais moderna, organizam-se em função da mais-valia relativa, sem necessariamente abolir a absoluta, enquanto as pequenas empresas, que por razões óbvias não conseguem atingir o mesmo nível de desenvolvimento, recorrem aos mecanismos da mais-valia absoluta, em que vicejam as formas precárias de trabalho interiores à produção capitalista (TAVARES, 2004, p.125).

Pode-se dizer que, nesse momento histórico, o trabalho polivalente, aliado ao trabalho informal, promove a articulação da mais-valia relativa à mais-valia absoluta, configurando um modelo de exploração perfeitamente adequado às exigências de acumulação, no qual a informalidade não pode mais ser vista como intersticial porque a realidade oferece múltiplos indícios de que esta tende a ser essencial.

$\mathrm{O}$ volume de produção pode ser aumentado, o ritmo de trabalho não tem controle, as horas extraordinárias são constantes. A relação patrãotrabalhador tende a ser descaracterizada em função da proximidade destes dois. [...] estresse, desvio de identificação, isto é, o trabalhador tende a ser envolvido pela dinâmica desenvolvida pelo patrão e perder a identidade com o seu trabalho, com sua classe e consigo mesmo. A consequência é o desenvolvimento de uma espécie de fragmentação da personalidade (personalidade esquizóide), depressão e alienação (TAVARES, 2004, P. $183)$.

Buscando definir os conceitos de mais valia-absoluta e mais valia-relativa é que Julio (2003) afirma que:

Mais valia absoluta, se manifesta na extensão da jornada de trabalho, via treinamento de qualificação, visto que essa qualificação é volátil e não traz nenhum retorno ao trabalhador a não ser sua conservação em seu posto de trabalho, o produto desenvolvido no interior da atividade de treinamento se caracteriza por um produto abstrato e pode ser transportado para o interior da jornada formal de trabalho. Uma forma inédita de recriação de formas passadas de exploração do trabalho que vem (mais-valia absoluta subsumida a mais-valia relativa) alimentar o processo de exploração sob a forma predominante de mais-valia relativa no interior da jornada formal de trabalho. A mais valia-relativa é característica de um período de desenvolvimento do capitalismo sob a forma de subsunção formal do trabalho ao capital, ou seja, o período em que o capital organiza as forças produtivas sem alterar a sua forma tecnológica (JULIO, 2003, P. 134).

Analisando a mais-valia relativa o autor afirma que:

A mais valia-relativa se caracteriza pela potencialização do grau de exploração possibilitada pelas novas tecnologias, ou seja, o aumento do grau de exploração compreende a diferença do produto criado pelo trabalhador e o que ele consome ou a redução do tempo de trabalho necessário à sua reprodução enquanto força de trabalho [...] a mais- valia relativa se caracteriza por um momento em que o capital- enquanto necessidade de aumentar ou conservar em nível mínimo o tempo gasto na reprodução da força de trabalho seja pela pressão da própria concorrência 
dos mercados, ou pela organização e resistência do proletariado em melhorar suas condições materiais e regulamentar a jornada de trabalho é forçado a revolucionar seu processo tecnológico (JULIO, 2003, P. 134$135)$.

Marx (1989), afirma que mais-valia absoluta e mais-valia relativa se complementam, segundo o autor:

$\mathrm{O}$ prolongamento da jornada de trabalho além do ponto em que o trabalhador teria produzido apenas um equivalente pelo valor de sua força de trabalho, e a apropriação desse mais trabalho pelo capital- isso é a reprodução da mais-valia absoluta. Ela constitui a base geral do sistema capitalista e o ponto de partida para a produção de mais-valia relativa. Com esta a jornada de trabalho está desde o princípio dividida em duas partes: trabalho necessário e mais trabalho. Para prolongar o mais trabalho reduz-se o trabalho necessário por meio de métodos pelos quais o equivalente do salário é produzido em menos tempo. A produção de mais valia absoluta gira em torno da duração da jornada de trabalho: a produção da mais valia relativa revoluciona de alto a baixo os processos técnicos do trabalho e dos agrupamentos sociais (MARX, 1989, p. 102).

Como mencionamos acima, hoje combinam-se os dois processo, a mais-valia relativa e a mais valia-absoluta. A intensificação do trabalho via o segundo caso, aliada à extração do sobretrabalho do trabalhador, acumulada pelos capitalistas, permitiram desenvolver as tecnologias e intensificar a produção, sob o mesmo tempo de trabalho. Contudo, além de possibilitar a ampliação da produção, nesse mesmo tempo, as tecnologias também permitiram aos capitalistas estenderem a jornada de trabalho até as casas dos trabalhadores, os fins de semana, as noites, os feriados e o lazer, que se transformaram em tempos preciosos e sagrados para o capital.

\section{Intensificação do Ritmo e da Jornada de Trabalho}

O que vem crescendo cada vez na produção capitalista, é o trabalho por atividade executada, realizada, contribuindo para acumulação cada vez maior por parte do capital, pois este tipo de trabalho "exige" e estimula que os trabalhadores trabalhem em ritmo cada vez mais rápido para produzir mais. Como em muitos casos, os trabalhadores não fazem parte de categorias de trabalhadores com jornadas ainda protegidas, estes mesmos trabalhadores realizam jornadas mais extensas. Isso em se tratando de um processo de produção, onde outros trabalhadores desenvolvem, por exemplo, atividades na linha final de produção, acaba por forçar também o aumento de sua própria jornada para "dar conta do recado".

Esse tipo de trabalho já era apontado por Marx, no século XIX. Era um processo de terceirização que externalizava ou mesmo internalizava a exploração do trabalho pelo método de pagamento, dentre outros mecanismos. Esse método de pagamento segundo Marx, "nada mais é que uma forma metamorfoseada do salário por tempo, do mesmo modo que o salário por tempo é a forma metamorfoseada do valor ou do preço da força de trabalho" (MARX, 1989, P. 139).

O salário por peça cria a aparência de que o valor de uso vendido já encontra-se objetivado no produto. Mas, ainda segundo Marx, o salário por peça não é determinado pela capacidade de produção do produtor, senão pela mesma fração do salário por tempo, 
cujo numerador é o valor diário da força de trabalho sobre uma jornada de trabalho de dado número de horas.

Ao analisar esta forma de pagamento em sua época, Marx (2001) aponta que esta forma de salário revela um sistema hierarquicamente organizado de exploração e opressão:

O salário por peça facilita que, entre o capitalista e o trabalhador assalariado, se insiram parasitas que subalugam o trabalho. $\mathrm{O}$ ganho dos intermediários decorre da diferença entre o preço do trabalho que o capitalista paga e a parte desse preço que ele realmente entrega ao trabalhador. Chama-se isto, na Inglaterra, de 'sistema de suadouro' (sweating system), Em outra forma, o salário por peça permite ao capitalista contratar o trabalhador principal - na manufatura como chefe de um grupo, nas minas como extrator de carvão, na fábrica como operário que maneja a máquina etc.- estabelecendo um tanto por peça, um preço pelo qual o trabalhador principal se obriga a recrutar e a pagar seus auxiliares. A exploração dos trabalhadores pelo capital se realiza então por meio da exploração do trabalhador pelo trabalhador (MARX, 2001, p. 640).

Marx (2001) entende a forma de pagamento "por peça" como uma forma "metamorfoseada" do salário por tempo, um meio de intensificar mais o trabalho e também dar vazão ao aumento da jornada de trabalho. O trabalhador, se quer ganha mais, no entanto, tem que trabalhar mais. Por isso, tais formas de trabalho convivem juntas, representando formas mistificadas do pagamento da força de trabalho.

Ao refletir também sobre o salário por peça, Tavares (2004) observa que à primeira vista este tipo de salário parece assegurar certa liberdade ao trabalhador:

O indivíduo tem a impressão de não estar submetido ao controle direto do patrão, podendo escolher quantas horas vai trabalhar diariamente. No entanto, a fração que serve de base para fixar o seu salário, ou, se preferirmos, o valor de cada peça, já contém o tempo de trabalho socialmente necessário. Isto é, a experiência já demonstrou qual o tempo de trabalho médio que se corporifica num quantum determinado daquele tipo de mercadoria, o que serve como parâmetro ao capitalista para definir o salário por peça. Assim, para ganhar mais, o trabalhador ou eleva a intensidade do trabalho ou prolonga a jornada de trabalho. Porém, ao aplicar mais intensamente a sua força de trabalho, permite ao capitalista elevar o grau normal de intensidade, rebaixando, assim, o preço do trabalho, com o que todos os trabalhadores serão prejudicados (TAVARES, 2004, P. 146).

Segundo Tavares (2004) essa transferência de papéis que Marx denuncia na contratação do trabalho mediante salário por peça, pode ser verificada em outras situações, na sociedade contemporânea. Por exemplo, na relação do capital com a sua rede de vendedores desconhecidos, os quais, ao invés de empregados do capital, assumem o papel de comerciantes, na medida em que têm um papel intermediário entre o capitalista, dono das mercadorias e os compradores, consumidores finais. A relação, ao mesmo tempo, esconde a subordinação do trabalho ao capital, elimina a responsabilidade direta do capitalista por qualquer aspecto do produto que gere insatisfação ao consumidor e conduz os consumidores, por meio do poder de convencimento do vendedor, a adiantarem $\mathrm{o}$ pagamento das mercadorias e o salário do próprio vendedor. 
Os trabalhadores, podem muitas vezes serem iludidos pela aparência enganadora dos fenômenos econômicos, mas eles sabem que o trabalho, como qualquer outra mercadoria, está submetido às flutuações do mercado. E quando há muita oferta e pouca procura, a defesa possível é ter um emprego. Se não os põem na rua, aumenta-se o seu trabalho, reduz-se o seu salário, e ainda assim o trabalhador adota ações de caráter defensivo. Ou seja, o pagamento por peça é uma forma de intensificação do trabalho.

Não é casual que uma função-chave, como o corte de couro, seja externalizada e submetida a essa forma de remuneração. Ao adotar o pagamento por peça para uma operação que faz deslanchar todas as outras, está sendo impresso um ritmo de trabalho mais intenso às etapas seguintes. Como a fração que serve de base para fixar o valor de cada peça é o tempo de trabalho socialmente necessário, o trabalhador, para ganhar mais, eleva a intensidade do trabalho, prolonga a jornada de trabalho ou incorpora toda a força de trabalho familiar disponível, inclusive das crianças:

Ao aplicar mais intensamente sua força de trabalho ou ao incorporar o trabalho não-pago da família para obter uma maior produção, o trabalhador domiciliar não sabe que está criando condições para o capitalista rebaixar o custo do seu trabalho e de todos os outros trabalhadores envolvidos naquela mesma atividade, pois o tempo médio de trabalho para a realização da mesma operação pode, a partir dessa nova base, ser alterado (TAVARES, 2004, p. 182).

Outra forma de transferência de responsabilidade do patrão para o empregado se expressa em certas práticas apontadas como "democráticas". Partindo do princípio de que o trabalhador conhece melhor que ninguém o seu trabalho, o capital conclui que a sua iniciativa individual não deve ser reprimida. Ao contrário, deve-se atribuir ao trabalhador um pseudo-autoridade e deixar que a dominação do trabalho se exerça pelo mercado. $\mathrm{Ou}$ seja, o capitalista conserva o completo controle do processo de produção em geral, mas faz de cada departamento em si uma empresa, dirigida por um trabalhador, que tem a obrigação de responder por tudo que ocorre naquela área, até pelos critérios de rentabilidade.

Ao pesquisar o setor têxtil e o trabalho no setor, Colli (2000) aponta algumas características do salário por peça. Segundo a autora este tipo de trabalho se resume em três pontos:

1) - A qualidade do trabalho é aqui controlada mediante o próprio produto, que tem de possuir qualidade média, se o preço por peça deve ser pago integralmente, tornando-se a fonte mais fecunda de descontos salariais e fraudes capitalista;

2) - O salário por peça proporciona ao capitalista uma medida inteiramente determinada para a intensidade do trabalho;

3) - O tempo de trabalho corporificado num quantum de mercadorias previamente determinado e fixado pela existência vale como tempo de trabalho socialmente necessário e é pago como tal (COLLI, 2000, p. 82).

A lógica do "salário por peça" está presente não somente nas indústrias que implantam técnicas do modelo japonês ou do toyotismo, forçadas a isso pelas mudanças nos padrões de competitividade e qualidade, mas também na extensa rede de serviços e de subcontratações. Podemos então deduzir que, tanto dentro como fora da indústria, existe algo dessa lógica em comum que se baseia na relação salarial individualizada e mensurada 
pela produtividade (pelo número de peça produzidas). Assim, essa lógica se coloca concretamente nas relações de produção do padrão de acumulação flexível, a partir da venda do trabalho objetivado(Colli, 2000, p. 85).

Segundo este autor (2000)

o salário por peça, permite então intensificar e estender a jornada de trabalho, algo muito comum no façonismo, principalmente devido à maneira informal com que os contratos de trabalho são estabelecidos individualmente, incentivados pela relação de "confiança", que deve haver entre as empresas subcontratantes e subcontratadas, mesmo no novo façonismo. A criação de excedentes de força de trabalho que trabalham sob o regime da mais-valia absoluta é uma estratégia produtiva combinada à extração da mais-valia-relativa. A flexibilização do trabalho permite tanto diminuir quanto aumentar a jornada de trabalho e nesse sentido ela pode aos poucos se 'dês-regulamentar'. A individualização das relações salariais sem a presença do sindicato demonstra como a lógica do "salário por peça" abrange toda a estratégia de produção flexível, não mais como um excedente de força de trabalho, mas tendendo cada vez mais a se tornar um regime de trabalho (COLLI, 2000, P. 87).

$\mathrm{Na}$ medida em que observamos os processo de trabalho, verificamos que estão crescendo a cada dia mais, de diversas formas e em todos os setores da produção capitalista. O sistema bancário é o trabalhador contratado por dia, para trabalhar por compensação efetuada. Muitas cooperativas recebem por peças feitas. No setor têxtil, se paga também por peças feitas. No setor calçadista o trabalho a domicílio vem aumentando cada vez mais, e a forma de trabalho também se dá por pares de sapatos. Sendo que os trabalhadores para produzirem mais e assim ganharem mais, trabalham em alto ritmo e em muitos casos, muitas horas sem parar e sem prazo de parar, pois, quanto mais trabalha, "mais recebe". É um processo desumano de trabalho, que combina mais-valia relativa e mais-valia absoluta.

\section{Terceirização, Intensificação do Trabalho e trabalho Alienado}

Pelas pesquisas sobre terceirização podemos afirmar que os mecanismos de terceirização levam às últimas consequiências o trabalho precário, intenso, desprovido de qualquer sentido, alienado. Antunes (2000), ao verificar as transformações ocorridas no mundo do trabalho, aponta o trabalho como

momento fundante de realização do ser social e o 'motor decisivo do processo de humanização do homem'. Não foi outro o significado dado por Marx ao enfatizar que: 'Como criador de valores de uso, como trabalho útil, é o trabalho, por isso, uma condição de existência do homem, independentemente de todas as formas de sociedade, eterna necessidade natural de mediação do metabolismo entre homem e natureza $\mathrm{e}$, portanto, vida humana'. Esta formulação permite entender o trabalho como 'a única lei objetiva e ultra-universal dos ser social, que é tão 'eterna' quanto o próprio ser social; ou seja nasce simultaneamente com o ser social, mas que permanece ativa apenas enquanto esse existir (ANTUNES, 2000, P. 125). 
O trabalho é o ponto de partida do processo de humanização do ser social, também é verdade que, tal como se objetiva na sociedade capitalista, é degradado e aviltado. Tornase estranhado. $O$ que deveria se constituir na finalidade básica do ser social - a sua realização no e pelo trabalho - é pervertido e depauperado. O processo de trabalho se converte em meio de subsistência. A força de trabalho torna-se, como tudo, nesse modo de produção, uma mercadoria, cuja finalidade vem a ser a produção de outras mercadorias. $\mathrm{O}$ que deveria ser a forma humana de realização do indivíduo reduz-se à única possibilidade de subsistência do despossuído. Esta é a radical constatação de Marx: a precariedade e perversidade do trabalho na sociedade capitalista. Desfigurado, o trabalho torna-se meio e não "primeira necessidade" de realização humana.

$\mathrm{Na}$ formulação contida nos Manuscritos Econômicos e Filosóficos, destaca que

[...] o trabalhador decai a uma mercadoria e à mais miserável mercadoria, torna-se um ser estranho a ele, um meio da sua existência individual" (MARX, apud, ANTUNES, 2000, p. 126).

Ao tratar do trabalho alienado, Antunes e Alves (2004), apontam que a alienação/estranhamento é mais acentuada nos trabalhos mais precários. Segundo os autores:

\begin{abstract}
A alienação/estranhamento é ainda mais intensa nos estratos precarizados da força humana de trabalho, que vivenciam as condições mais desprovidas de direitos e em condições de instabilidade cotidiana, dada pelo trabalho part-time, temporário, e precarizado. Sob a condição da precarização, o estranhamento assume a forma ainda mais intensificada e mesmo brutalizada, pautada pela perda (quase) completa da dimensão de humanidade. Nos estratos mais penalizados pela precarização/exclusão do trabalho, o estranamento e o fetichismo capitalista são diretamente mais desumanizadores e bárbaros em suas formas de vigência. E é o que estamos presenciando hoje, intensamente, em tantas partes do mundo e em particular na América Latina. [...] Sob a condição da separação absoluta do trabalho, a alienação assume a forma de perda de sua própria unidade: trabalho e lazer, meios e fins, vida pública e vida privada, entre outras formas de disjunção dos elementos de unidade presentes na sociedade do trabalho. Expandem-se, desse modo, as formas de alienação dos que se encontram à margem do processo de trabalho (ANTUNES \& ALVES, 2004, p. 348).
\end{abstract}

Analisando sobre a quantidade de trabalhadores desempregados, Antunes e Alves (2004), apontam que as formas de absolutização da alienação são diferenciadas. Variam da rejeição da vida social, do isolamento, da apatia e do silêncio (da maioria) até a violência e agressão diretas. Aumentam os focos de contradição entre os desempregados e a sociedade como um todo, entre a "racionalidade" no âmbito produtivo e a "irracionalidade" no universo societal.

Sob a mudialização do capital, caracterizada pelo desemprego estrutural, pela redução e precarização das condições de trabalho, evidencia-se a existência de uma materialidade adversa aos trabalhadores, um solo social que constrange ainda mais o afloramento de uma subjetividade autêntica, ou seja, de uma subjetividade para-si. Existe um enorme controle do trabalhador, no trabalho, pelo capital, sendo, inclusive, estendido para fora do trabalho, para a sua casa e para a rua. Nos tempos "livres", o domínio do capital se dá, por exemplo, pela necessidade criada pelo consumo nos shoppings, 
colocando obstáculos ao desenvolvimento de uma subjetividade autêntica, ou seja, uma subjetividade capaz de aspirar a uma personalidade não mais particular nem meramente reduzida a sua "particularidade". A alienação/estranhamento e os novos fetichismos que permeiam o mundo do trabalho tendem a impedir a autodeterminação da personalidade e a multiplicidade de suas qualidades e atividades.

Nos Manuscritos Econômicos e Filosóficos (1844) Marx, parte de uma análise crítica da economia política, seus conceitos e pressupostos, mostram a determinação da propriedade privada sobre o trabalhador. O autor (2004) já se demonstra comprometido com um projeto político de emancipação humana. Marx já trabalha com a possibilidade de transformação da sociedade via revolução do proletariado. Em seus estudos, Marx constata que quanto mais riqueza produz mais pobre fica o trabalhador. $\mathrm{O}$ trabalhador nada mais é, na sociedade capitalista, do que uma mercadoria. O pior, é que esta mercadoria - o trabalhador - é uma mercadoria que serve para produzir e criar outras mercadorias (riqueza), no entanto, quanto mais mercadoria cria, mais barato ele fica. Além de servir para criar mercadorias, no trabalho, o trabalhador produz a si mesmo.

[...] Com a valorização do mundo das coisas aumenta em proporção direta a desvalorização do mundo dos homens. O trabalho não produz só mercadorias; produz a si mesmo e ao trabalhador como uma mercadoria, e isto na proporção em que produz mercadorias em geral (MARX, 1989, p. 148).

Para Marx, só é possível apreender o processo real da alienação quando se tem o trabalho como essência da propriedade privada. Isto permite penetrar a determinação real do movimento econômico. Entende Marx, que a alienação é um processo metamorfoseado, pois o sujeito da produção, o trabalhador, está na mercadoria de forma objetivada, alienada. O trabalhador, que com sua força de trabalho - para utilizar um conceito que Marx desenvolveu mais tarde - produz as mercadorias, vê-se desefetivado e condenado a morrer de fome. O processo é extremamente aviltante, pois o trabalhador é expropriado e despojado de tudo, com exceção de sua força de trabalho. Não só os objetos de sua produção - as mercadorias, mas também os objetos de trabalho, os instrumentos e meios de produção, tornam-se-lhes alheios e estranhos. Desta forma, acontece a mágica da multiplicação do capital. Marx chega a afirmar que até mesmo o trabalho torna-se uma coisa difícil para o trabalhador se apropriar.

[...] A apropriação do objeto tanto aparece como alienação que, quanto mais objetos o trabalhador produz, tanto menos pode possuir e tanto mais cai sob o domínio do seu produto, do capital. Todas estas consequências estão, na determinação de que o trabalhador se relaciona com o produto do seu trabalho como / com/ um objeto alheio. Pois segundo este pressuposto está claro: quanto mais o trabalhador se gasta trabalhando, tão mais poderoso se torna o mundo objetivo alheio que ele cria frente a si, tão mais pobre se torna ele mesmo, o seu mundo interior, tanto menos/ coisas/ lhe pertence/ m/ como seu /suas / próprio/ as / [...] (MARX, 1989, p. 150).

Este mundo coisificado, objetivado, exteriorizado "independente" e estranho ao trabalhador cresce em proporção ao aumento de produção das mercadorias. Poderíamos dizer que quanto mais desenvolvem-se as forças produtivas da sociedade mais o mundo torna-se estranho e alheio ao trabalhador, porque 
[...] A exteriorização do trabalhador em seu produto tem o significado não só de que o seu trabalho se torna um objeto, um existência independente de e alheia a ele, tornando-se um poder autônomo frente a ele, / o significado/ de que a vida que ele conferiu ao objeto se lhe defronta inimiga e alheia. (MARX, 1989, p. 151).

O trabalhador torna-se servo dos objetos de sua produção, que se tornam cada vez mais alheios e estranhos para ele.

[...] O trabalho produz maravilhas para os ricos, mas produz desnudez para o trabalhador. Produz palácios, mas cavernas para o trabalhador. Produz beleza, mas mutilação para o trabalhador. Substitui o trabalho por máquinas, mas joga uma parte dos trabalhadores de volta a um trabalho bárbaro e faz da outra parte máquinas. Produz espírito, mas produz idiotia, cretinismo para o trabalhador. (MARX, 1989, p. 152).

A alienação do trabalhador, para Marx, ocorre em dois aspectos que são inseparáveis, pois um é a determinação do outro. O primeiro aspecto é o que temos discutido até aqui, ou seja, a alienação do trabalhador com o resultado e o produto do seu trabalho, que tornam-se objetos estranhos e alheios a ele. A relação do trabalhador com o mundo exterior sensorial, com a natureza e seus objetos. O segundo aspecto, que é a determinação do primeiro, é o fato da alienação do trabalhador não ocorrer apenas no resultado da produção, no produto do seu trabalho. A alienação se dá no ato da produção, na atividade em si, no desgaste da capacidade física e intelectual do trabalhador, no uso de usa força de trabalho. O produto do trabalho só é exteriorizado, objetivado, coisificado, enfim, alienado, porque o trabalhador se exterioriza, objetiva-se, coisifica-se e se aliena de si na atividade produtiva, no trabalho. A alienação do objeto, do produto do trabalho é apenas o resumo da alienação, da exteriorização da atividade produtiva do trabalho, "da relação do trabalho com o ato da produção dentro do trabalho".

[...] é a relação do trabalhador com a sua própria atividade como uma / atividade/ alheia não pertencente a ele, a atividade como sofrimento, a força como impotência, a procriação como emasculação, a energia mental e física própria do trabalhador, a sua vida pessoal [...] como uma atividade voltada contra ele mesmo, independente dele, não pertencente a ele[...] (MARX, 1989, p. 154).

Marx aponta ainda uma terceira determinação do trabalho alienado como consequência das duas abordadas até aqui. Trata-se da questão do ser genérico do homem. Esta é uma reflexão que apreende a relação do homem consigo mesmo, com o seu gênero, com as coisas, com a natureza exteriorizada, enfim, com o mundo a partir do seu trabalho. Marx parte do pressuposto que a natureza é a fonte que permite ao homem criar as coisas.

O trabalhador cria e produz as coisas a partir da sua relação com a natureza e com o mundo exterior sensorial. Entende Marx, que a natureza oferece os meios de vida do trabalho, pois, sem ela é impossível haver trabalho. Mas a natureza oferece também os meios de vida do trabalhador, a sua subsistência física. É a capacidade de agir sobre a natureza, de apropriar-se dela que distingue os homens dos animais. Ora, a natureza é ao mesmo tempo um meio de vida imediato e o meio de efetivação do homem pelo trabalho, como "matéria, objeto e instrumento de sua atividade". O homem e a natureza estão interligados, um não pode existir sem o outro, são inseparáveis, completam-se numa totalidade. "[...] Que vida física e mental do homem está interligada com a natureza não 
tem outro sentido senão que a natureza está interligada consigo mesma, pois o homem é uma parte da natureza" (MARX, 1989, p. 155).

O trabalho, a capacidade de produzir e criar as coisas é que humaniza o homem. O homem se faz homem em relação com os outros homens e com a natureza. Não obstante, é o trabalho também que tem a capacidade de roubar do homem a sua essência, roubandolhe inclusive a natureza, objetivando-o e coisificando-o, tornando-o um negação do homem. O trabalho pode anular o homem, fazer dele um não-homem ao roubar a sua autonomia e a sua liberdade diante da natureza, do mundo exteriorizado, à medida que se aliena.

[...] Na medida em que o trabalho aliena do homem 1. a natureza e 2. a si mesmo, a sua função ativa própria, a sua atividade vital, aliena do homem o gênero; lhe faz da vida do gênero um meio de vida individual. Em primeiro lugar aliena a vida do gênero e a vida individual, e em segundo lugar faz da última em sua abstração um fim da primeira, igualmente na sua forma abstrata e alienada (MARX, 1989, p. 155).

Isto é o máximo da alienação e desfiguração humana, pois o trabalho, a princípio, aparece aos homens apenas como um meio para satisfazerem suas necessidades. A partir do trabalho, apropriando-se da natureza os homens conseguem o necessário para a manutenção da vida física. "Mas a vida produtiva é a vida do gênero". No trabalho o homem distingue-se dos animais. A partir do trabalho - que Marx atribui o conceito de atividade vital, o homem faz de sua vida uma essência genérica. $\mathrm{O}$ homem relaciona-se com o gênero relaciona-se consigo próprio. É a partir do trabalho que constrói o mundo. $\mathrm{Na}$ alienação, entretanto, volta ao estado animal, pois reduz a sua atividade a comer, beber, vestir etc. A alienação priva o homem da criatividade, da cultura, limita-o apenas à luta pela subsistência. A alienação torna o homem um ser estúpido, pois reduz a sua necessidade à mais miserável manutenção da vida física, torna a sua atividade a mais mecânica possível, faz dele um ser despojado do gozo e da essência da vida humana. O homem é reduzido a servo do seu objeto, do seu produto.

[...] O homem faz da sua atividade vital mesma um objeto do seu querer e da sua consciência. Tem atividade vital consciente. Não é uma determinidade com a qual ele conflua imediatamente. A atividade vital consciente distingue o homem imediatamente da atividade vital animal. É precisamente só por isso que ele é um ser genérico. Ou ele só é um ser consciente, isto é, sua própria vida lhe é objeto, precisamente porque é um ser genérico. Só por isto a sua atividade é atividade livre. O trabalho alienado inverte a relação de maneira tal que precisamente porque é um ser consciente o homem faz da sua atividade vital, da sua essência, apenas um meio para a sua existência (MARX, 1989, p. 156).

Ao contrário dos animais, o homem não possui limites, produz universalmente. Os animais só produzem para atender as necessidades físicas, o homem, por sua vez, produz independentemente delas, aliás, produz melhor se estiver livre dela. $\mathrm{O}$ homem reproduz a natureza, defronta-se com o produto do seu trabalho; os animais permanecem no limite da natureza. O homem apropria-se da natureza de forma global, como ser total. Para Marx, a atividade humana é sempre individual, mas apropria-se de forma coletiva, na relação com os outros homens. $\mathrm{O}$ homem produz como um ser social. A natureza apenas existe para $\mathrm{O}$ homem enquanto ser social. Só neste sentido a natureza pode ser humanizada, tornar-se efetiva para o homem. Desta forma, a natureza torna-se para o homem sua forma de vida 
natural e humana. A sociedade humana é por isso a plena articulação do homem com a natureza, consigo próprio e com os outros homens. O trabalho faz produz uma unidade essencial do homem com a natureza. Mas o trabalho alienado tira do homem a sua essência ao roubar-lhe a natureza.

[...] Portanto, é precisamente ao trabalhar o mundo objetivo que o homem primeiro se prova de maneira efetiva como um ser genérico. Esta produção é a sua vida genérica operativa. Por ela a natureza aparece como a sua obra e a sua realidade efetiva. O objeto do trabalho é, portanto, a objetivação da vida genérica do homem: ao se duplicar não só intelectualmente tal como na consciência, mas operativa, efetivamente e, portanto, ao se intuir a si mesmo num mundo criado por ele. Por conseguinte, ao arrancar do homem o objeto da sua produção, o trabalho alienado lhe arranca a sua vida genérica, a sua objetividade vantagem ante o animal na desvantagem de lhe ser tirado o seu corpo inorgânico, a natureza (MARX, 1989, p. 157).

A alienação distancia o trabalhador da natureza e de si próprio, num processo fetichista, que faz com que ele não mais se reconheça no seu trabalho e no resultado exteriorizado do mesmo. Este é o segredo que permite o domínio de uma classe sobre a outra. O trabalhador não percebe que a origem da riqueza está no trabalho alienado. Desta forma, o trabalho alienado desfigura o homem, faz com que a sua atividade - o trabalho -, vida genérica, seja apenas um meio para a sua existência física. Neste ponto, Marx demonstra como a alienação do trabalho faz do homem um ser que, ao trabalhar, desfigura-se em todos os sentidos, pois faz.

[...] do ser genérico do homem, tanto da natureza quanto da faculdade genérica espiritual dele, um ser alheio a ele, um meio da sua existência individual. Aliena do homem o seu próprio corpo, tal como a natureza fora dele, tal como a sua essência espiritual, a sua essência humana. Uma conseqüência imediata do fato de o homem estar alienado do produto do seu genérico, é o homem estar alienado do homem. Quando o homem está frente a si mesmo, então o outro homem está frente a ele[...] (MARX, 1989, p. 158).

De tudo isto é óbvio concluir - como fez Marx - que o trabalhador se nega em seu trabalho. Que o trabalho é uma coisa exteriorizada e alheia ao trabalhador, que não pertence à sua essência. No trabalho, o trabalhador não se sente bem, não é um ser criativo, pois sua liberdade e criatividade são tolhidas. O trabalho ao invés de libertar e dignificar o homem, tornou-se-lhe um infortúnio, um fardo terrível, um instrumento de tortura, é fonte de desgraça, uma praga pestilenta. No caso do trabalhador, pode aplicar-se a explicação teológica tão decantada "ganharás o pão com o suor do seu rosto", acrescentando, porém, que o pão alheio também tem que sair do suor do trabalhador.

[...] Daí que o trabalhador só se sinta junto a si fora do trabalho e fora de si no trabalho. Sente-se em casa quando não trabalha e quando trabalha não se sente em casa. $\mathrm{O}$ seu trabalho não é, portanto, voluntário, mas compulsório, trabalho forçado. [...] não é a satisfação de uma necessidade, mas somente um meio para satisfazer necessidades fora dele. A sua alienidade emerge com puereza no fato de que, tão logo não exista coerção física ou outra qualquer, se foge do trabalho como de uma peste. O trabalho exterior, o trabalho no qual o homem se exterioriza, é 
um trabalho de auto-sacrifício, de mortificação[...] (MARX, 1989, p. 153).

Como se exprime o conceito de trabalho exteriorizado, alienado? Como isso se apresenta na realidade? Quem se apropria deste trabalho alienado, da riqueza criada e produzida por ele? Se o trabalho é alienado, o seu produto, o resultado de sua criação tem que ficar com um ser alheio ao trabalhador. Ora, mas que ser misterioso é este que consegue realizar este ato de galhardia apropriando-se do produto e do trabalho alheio, num gesto digno de devoção. Este ser obviamente só pode ser outro homem.

O produto do trabalho não pertencendo ao trabalhador, sendo-lhe um objeto estranho, alheio e exterior, um poder desconhecido que paira acima dele, só é possível porque o produto do trabalho pertence a um outro homem. A mesma atividade que é tormento, auto-sacrifício, mortificação e desgraça para o trabalhador é fonte de gozo, alegria e prazer para o não trabalhador, o capitalista. Só o homem pode ser o poder alheio que paira acima do trabalhador. É o próprio homem quem se apropria do produto do trabalho alheio.

[...] Se, portanto, ele se relaciona com o produto do seu trabalho, com o seu trabalho objetivado, como com um objeto alheio, inimigo, poderoso, independente dele, então, relaciona-se com ele, de maneira tal que um independente dele, é o senhor deste objeto. Se se relaciona com a sua própria atividade como com uma atividade não livre, então ele se relaciona com ela como a atividade a serviço de, sob o domínio, a coerção e o jugo de um outro homem (MARX, 1989, p. 159).

O segredo que permite ao capitalista apropriar-se do trabalho e do produto do trabalho alheio está na essência do modo de produção capitalista. Ao expropriar o trabalhador de tudo, o capitalista, que é um ser despojado do trabalho, tem diante de si também um ser despojado de todos os meios que lhe permita viver, com exceção da sua força de trabalho. As necessidades humanas fazem com que se alugue por um determinado período, diário, semanal ou mensal, para conseguir sobreviver. É aí que aparece para o capitalista a oportunidade para reproduzir e multiplicar o seu capital, pois, contratando a força de trabalho do trabalhador, é ele, o capitalista que vai colocar o valor na mesma. Por outro lado, o trabalhador não está em condições de exigir que se lhe pague o valor real de seu trabalho. Tem que se alienar na produção e consumir no objeto de trabalho a sua energia física e mental, sua carne e seus nervos, fazendo com que o objeto se transforme em outro objeto, em mercadoria, acrescentando a este novo objeto, um novo valor o seu trabalho. Assim, ele cria, por meio do seu trabalho, a riqueza alheia.

[...] No mundo efetivo prático a auto-alienação só pode aparecer através da relação efetivamente real, prática com outros homens. O meio pelo qual procede a alienação é ele mesmo um meio prático. Pelo trabalho alienado, portanto, o homem não engendra apenas a sua relação com o objeto e com o ato de produção enquanto poderes alheios e inimigos dele; engendra também a relação na qual outros homens estão com a produção e o produto dele e a relação na qual ele está com estes outros homens. Tal como ele engendra a sua própria produção para a sua desefetivação [...], para o castigo, tal como engendra o seu próprio produto para a perda, para ser um produto não pertencente a ele, assim ele engendra a dominação daquele que não produz sobre a produção e sobre $\mathrm{o}$ produto[...] (MARX, 1989, P. 160). 
A Propriedade privada é o bastião que permite a apropriação do produto do trabalho alheio. A propriedade privada surge, entretanto, a partir do trabalho alienado, ela é produto e resultado da exteriorização do trabalhador, ela é uma consequiência necessária do trabalho exteriorizado. A propriedade privada erige, pois, a relação exterior do trabalhador com a natureza e consigo mesmo. Marx obteve da Economia Política os conceitos que exprimem o movimento da propriedade privada, a alienação e exteriorização do trabalho, a razão e causa do trabalho exteriorizado. Marx, entretanto, inverte esta ótica e afirma que a propriedade privada é uma consequência do trabalho exteriorizado. "[...] A propriedade privada resulta, portanto, por análise a partir do conceito de trabalho exteriorizado, isto é, de homem exteriorizado, de trabalho alienado, de vida alienada, de homem alienado..." (MARX, 1989, p. 161).

Marx atribui, ainda, à sociedade capitalista o momento em que a propriedade privada consegue apresentar-se das duas formas ao mesmo tempo: ser causa e conseqüência do trabalho exteriorizado.

[...] É só no último ponto de culminância do desenvolvimento da propriedade privada que emerge novamente este seu segredo, a saber, ser de um lado o produto do trabalho exteriorizado e em segundo lugar o meio pelo qual o trabalho se exterioriza, a realização desta exteriorização (MARX, 1989, P. 161).

A preocupação principal em Marx é com a emancipação humana a partir da superação da propriedade privada. Superar a propriedade privada para restabelecer o gozo, a efetividade, a objetividade e a primazia humana. Emancipar a humanidade pela superação da propriedade privada para resgatar os sentidos objetivos e subjetivos humanos.

A proposta de Marx se funda na questão de que, a superação da propriedade privada e a emancipação humana, só podem ocorrer a partir da emancipação de toda a humanidade da servidão e dos grilhões da própria propriedade privada, a partir da luta e da resistência da classe trabalhadora.

Partindo do pressuposto estabelecido por Marx e Engels na Ideologia Alemã, de que o homem é o que e como produz, depreende-se que o homem é educado pelo trabalho. Então, depende do modo de produção o tipo de homem educado e a ser formado. Portanto, tendo presente que o capitalismo se confunde com o trabalho alienado, a educação, como uma forma de trabalho, também não poderia deixar de genericamente produzir alienação. Diante disso, cabe à educação possibilitar o acesso aos conhecimento historicamente acumulados de tal modo que permitam compreender a sociedade e o modo de produção existentes e lutar contra ele, produzindo a desalienação e a emancipação do homem da atual forma de trabalho.

Marx critica as teorias que supostamente estão comprometidas com os interesses dos trabalhadores, mas buscam soluções que não passam pela revolução social, pela superação da propriedade privada, da exploração e da especulação que dela advém. Para Marx, teóricos como Proudhon, que querem construir uma igualdade de salários, fazer de todos os homens trabalhadores, caem numa visão abstrata do capitalismo, sem contribuir para a sua superação.

O compromisso de Marx, já nos Manuscritos Econômicos Filosóficos é com a emancipação humana, que passa obrigatoriamente pelos trabalhadores. Ao contrário de Durkheim, portanto, Marx não vê na divisão social do trabalho uma fonte de solidariedade social, mas sim, uma fonte de alienação dos trabalhadores. 


\section{Referências}

ANTUNES, Ricardo. Adeus ao trabalho?: ensaio sobre as metamorfoses e a centralidade do mundo do trabalho. São Paulo, Cortez, 2000.

Ricardo. Trabalho e superfluidade. In: Capitalismo, trabalho e educação. Campinas: Autores \& Associados, 2002.

Associados, 2004.

Desertificação neoliberal no Brasil. Campinas: Editora Autores \& A dialética do trabalho. São Paulo: Expressão Popular, 2004.

As mudanças no mundo do trabalho na era da mundialização do capital. Educação e Sociedade, n. 87, mai./ ago., 2004. n. 6, 1999.

Os novos proletários do mundo na virada do século. Revista Lutas Sociais,

Os sentidos do trabalho: ensaio sobre a afirmação e a negação do trabalho. São Paulo: Boitempo, 1999.

ANTUNES, Ricardo \& ALVES, Giovanni. As mutações no mundo do trabalho na era da mundialização do capital, in: Educação e Sociedade, vol. 25, n. 87, p. 335-351, maio/ago. Cedes, Campinas, 2004.

ALVES, Giovanni. A nova degradação do trabalho na era da globalização. Londrina: Práxis, 1999.

. O novo (e precário) mundo do trabalho: reestruturação produtiva e crise do sindicalismo. São Paulo: Boitempo, 2000.

AMORIM, Elaine Regina. No limite da precarização: terceirização e trabalho feminino na indústria de confecção. 2003. Tese (doutorado) - Universidade Estadual de Campinas, Instituto de Filosofia e Ciências Humanas.

BATISTA, Roberto Leme. Desafios do trabalho, capital e luta de classes no século XXI. Londrina: Práxis, 2003.

A educação profissional na década neoliberal: o caso do Planfor. 2002. Dissertação (Mestrado) - Universidade Estadual Paulista "Júlio de Mesquita Filho" Unesp, Marília.

BIHR, Alain. Da grande noite à alternativa: o movimento operário europeu em crise. São Paulo: Boitempo, 1998.

BRAVERMAN, Harry. Trabalho e capital monopolista: a degradação do trabalho no século XX. Rio de Janeiro: Guanabara, 1987.

CASTEL, Robert. As metamorfoses da questão social, uma crônica do salário. 2. ed. Petrópolis: Vozes, 1999.

CATTANI, Antonio David. Dicionário crítico sobre trabalho e tecnologia. São Paulo: Vozes, 2002.

COLLI, Juliana. A Trama da Terceirização: um estudo do trabalho no ramo de tecelagem, Campinas, Editora da Unicamp, 2000. 
DRUCK, Maria da Graça. Flexibilização, terceirização e precarização: a experiência dos sindicatos. In: FRANCO, Tânia. Trabalho, riscos industriais e meio ambiente: rumo ao desenvolvimento sustentável? Salvador: EDUSBA, 1997.

GOUNET, Thomas. Fordismo e Toyotismo na civilização do automóvel. São Paulo: Boitempo, 1999.

HARVEY, David. Condição pós-moderna. São Paulo: Loyola, 2000.

HELOANI, Roberto. Gestão e organização no capitalismo globalizado: história da manipulação psicológica no mundo do trabalho. São Paulo: Atlas, 2002.

Organização do trabalho e administração: uma visão multidisciplinar. São Paulo: Cortez, 2002.

JULIO, Marcelo. Crise do capital, reestruturação produtiva e qualificação profissional. In. BATISTA, Roberto Leme. Desafios do trabalho: capital e luta de classes no século XXI. Londrina: Práxis, 2003.

MARX, Karl. Trabalho alienado e superação positiva da auto-alienação humana, in: FERNANDES, Florestan, Marx e Engels. São Paulo, Ática, 1989.

MARX, Karl. A ideologia alemã (Feuerbach). 11 ed. Editora São Paulo: Hucitec, 1999.

MARX, Karl. O Capital: Crítica da Economia Política, Livro I, O Processo de Produção do Capital, Vol. II, $17^{\circ}$ Ed. Rio de Janeiro, Civilização Brasileira, 2001.

Boitempo, 2004.

Manuscritos econômicos e filosóficos; tradução de Jesus Ranieri. São Paulo:

POCHMANN, Marcio. O emprego na globalização: a nova divisão internacional do trabalho e os caminhos que o Brasil escolheu. São Paulo: Boitempo, 2002.

O movimento de desestruturação do mercado de trabalho brasileiro nos anos 90: uma análise regional. Economia e Sociedade, Campinas, IE/ Unicamp, n.9, 1998.

TAVARES, Maria Augusta. Os fios (in) visíveis da produção capitalista: informalidade e precarização do trabalho. São Paulo: Cortez, 2004.

\footnotetext{
${ }^{\text {i }}$ Doutor em História e Filosofia da Educação pela Unicamp, docente do Curso de Pedagogia da Unioeste e Pós-doutorando em Educação por esta mesma instituição, membro do Grupo de Pesquisa Histedopr. E-mail: eraldo_batista@hotmail.com

ii Doutor em História e Filosofia da Educação pela Unicamp, docente do Curso de Pedagogia e do Mestrado em Educação da Unioeste, líder do Grupo de Pesquisa Histedopr. E-mail: paulinorso@uol.com.br
} 